\title{
The Relationship between Interest Rates, Income, GDP Growth
}

\section{and House Prices}

\author{
Ting $\mathrm{Xu}^{1^{*}}$ \\ ${ }^{1}$ Postgraduate in Nottingham Trent University, Xi'an City, Shaanxi Province, China \\ *Ting Xu, E-mail: fanny85117@hotmail.com
}

Received: December 9, 2016

Accepted: December 30, 2016 Online Published: January 6, 2017

doi: $10.22158 /$ rem.v2n1p30

URL: http://dx.doi.org/10.22158/rem.v2n1p30

\begin{abstract}
This paper will analyse the relationship between interest rate, income, GDP growth and house prices. First, the control power of interest rate for the prices is limited. Second, people's income increases, thus that also increases the demand for housing. But house prices are too high and will cause buying pressure. Third, the real estate industry's growth and GDP growth have inseparable relationship, they interact with each other.
\end{abstract}

\section{Keywords}

real estate, economic, GDP, income, China

\section{Introduction}

Real estate exists as an essential industry; It draws the focus of people, because the housing industry represents a special kind of service - it can be used for trading and also used as an investment or business in itself. While house price formation is a complicated process - among house price driving factors are the GDP growth, income, employment and other reasons strongly affect housing supply and demand-interest rates and government policy and land price also strongly affect investment cost, investment income and investment risk.

Among these, the interest rate, the residents' income and GDP growth are the main factors which influence house prices - their relationship with each other and resultant influence upon the housing market will be addressed. In 1998, the Chinese government abolished the administrative housing allocation; as a result the Chinese real estate industry began to develop rapidly. There are obviously other factors affecting the housing market besides the aforementioned individual's income and national related interests, however these are of less effect and outside the scope of this paper. 


\section{Method}

Interest rates:

Interest rates as an implement of the government or Banks for monetary policies and national economic regulation have great importance; they have a strong regulatory role for real estate market supply and demand (Cavallo, 2010). This is as a result of the magnitude of the interest rate directly influencing the investment cost.

Primarily; if the interest rate lowers, then the cost of real estate investment will also lower, and the return on investment will be higher. So more exciting real estate investments will greater increase the market capacity of real estate.

Hypothesis; the real estate investment marginal efficiency is fixed, enterprise investment profit is equal to its expected return on investment after deducting the initial cost of investment.

$$
\Pi=\mathrm{TR}(\mathrm{I})-\mathrm{TC}
$$

Where $\Pi$ is the investment economic profit, TR (I) is the total expected return on an investment, TC (I) is the total cost of the investment (Cavallo, 2010).

The investment profit maximization condition: the investment of the profit margin $=$ the marginal cost of investment, thus the investment marginal cost is equivalent to the actual interest rate. The relationship between Interest rates and investment has been reversed decisions based on investment marginal efficiency curves (Cavallo, 2010).

Hypothesis interest rate is $I=I(r)$, reflecting the level of investment and interest rate of the relationship is reversed: $\quad I=\beta_{0}-\beta_{1 \mathrm{r}}$.

I is the level of investment, beta $\beta_{0}$ is the self living type of investment, interest rate is 0 ; it is for the necessary housing needs of the investment; $\beta_{1}$ is the influence degree of the interest rate on investment (Favara, 2009). This formula suggests that the marginal benefit investment under the invariable conditions and lower interest rates, result in the cost of the investment being lower, and the planned investment will be higher (Favara, 2009).

In 2010, the one-year benchmark interest rates rose twice by $0.25 \%$ in both cases (Hasson, 2010). The bank reserve interest rates also decreased four times in 2010 (Hasson, 2010). The people's bank of China has been trying to raise interest rates to reduce the real estate investment and the supply of housing. But the effect is not obvious; because the relationship of interest rates and investment amounts has been reversed, so that investment marginal efficiency is unchanged.

In terms of actual investment, the expected rate of return (marginal efficiency) is increasing because of the continued attraction of real estate investors and influx of their finance, which in turn further increases available property; despite the bank or governments attempts to prevent this with higher interest rates intended to deter investors (Qi \& Hua, 2007).

At this point, the investment cost-interest rates increase is limited, the increase of the expected rate of return is much higher than the increased cost of investment, thus interest rate increases only weakly regulate housing prices (Qi \& Hua, 2007). Regarding the aspect of consumer demand; as in the typical 
manner of modern consumption, loans or overdrafts have become the mainstream method of attaining property. Especially when buying a house, almost all people require mortgages from banks.

Obviously, when the bank interest rates are low, consumer's loan costs are reduced, thus this will promote consumers to obtain loans or mortgages to allow them to purchase property, and hence increase demand for housing. In 2008, China's real estate experienced a downturn; the Government implemented a series of preferential policies regarding interest rates. Primarily; for the first time individuals buying properties for the purpose of their own home, where these properties represent less than 90 square meters, then deed tax rates were provisionally reduced to 1\% (THE CENTRAL PEOPLE'S GOVERNMENT, 2008).

Secondly; the sale or purchase of individual housing was made temporarily free of tax stamp duty (THE CENTRAL PEOPLE'S GOVERNMENT, 2008). Finally; individual housing sales were temporarily freed of land value increment tax (THE CENTRAL PEOPLE'S GOVERNMENT, 2008). The interest rate was reduced and hence consumers loan costs decreased, stimulating an increase in demand to a certain extent.

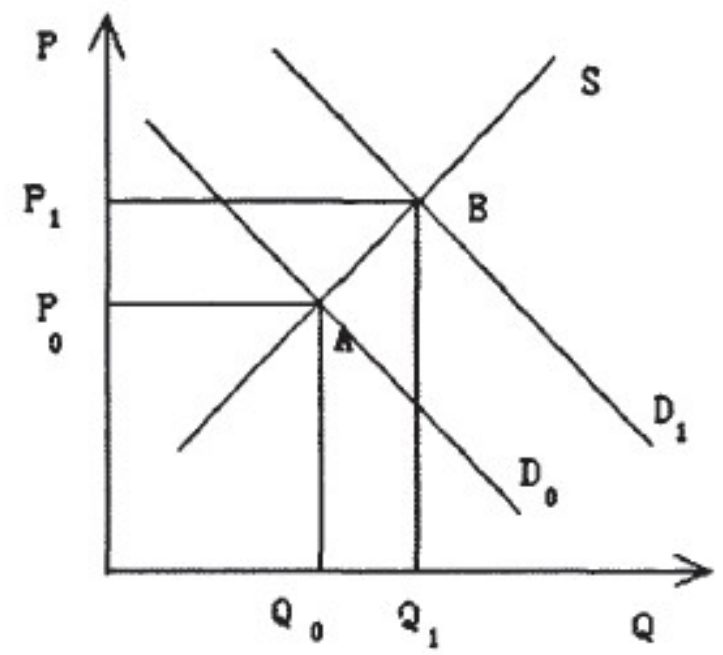

Figure 1. The Influence of Changes in the Demand for Equilibrium

P represents house prices,

$\mathrm{Q}$ is the demand for housing,

$\mathrm{D}_{0}$ is the initial demand curve, $\mathrm{S}$ is the housing supply curve,

The equilibrium for initial is $A, P_{0}$ is initial equilibrium house prices, $Q_{0}$ is housing sales when initial equilibrium.

Therefore; when the banks cut interest rates, the loan cost is reduced, thus people's demand for housing thereby increased (Sloman \& Garratt, 2010).

As the graph implies, when the housing demand value increased from $D_{0}$ to $D_{1}$, the supply curve shifted over to a new equilibrium point $\mathrm{B}$, then the new equilibrium price is $\mathrm{P}_{1}$ and the corresponding 
housing sales is $\mathrm{Q}_{1}$.

The Figure clearly shows, house prices are rising, and sales are increased (Sloman \& Garratt, 2010). Therefore, in the housing market demand, the change of interest rates can impact upon housing prices. When the real estate market becomes overwhelmed by an influx of investors or new property buyers, an increase in interest rates will dissuade real estate investment to a certain extent (Sloman \& Garratt, 2010). Conversely; it also raises a lot of consumer loan costs; when the expected rate of return for investors (marginal efficiency) is increasing, the increase of interest rates (investment cost) is lower than the expected rate of return, the increase of interest rate could not control the real estate investment, and hence its influence upon house prices is limited.

Income:

An increase in the income of residents will also have a great impact to house prices ( $\mathrm{Li}, 2008)$. Housing as an investment market is different to those of stocks, bonds, or funds, because property can also effectively be classed as consumer goods as well as representing a monetary investment or profitable industry.

Housing is durable, and as with other consumer goods has an intrinsic value. Income increases result in stimulation for people to improve their living conditions or climb the property ladder and thus drive demand for larger homes, thus putting greater strain on the available space or properties. Additionally, buying further properties as an investment becomes a more rational choice for more affluent residents. Since China's reform and opening up, Chinese people have greatly increased their income, the Engel coefficient has declined obviously, and consumption structure has escalated, investment ability has increased in strength. The change in the structure of family and the urbanisation process are raising the demand for housing. Purchase of real estate is one of the key popular choices that many are becoming involved in ( $\mathrm{Li}, 2008)$. The demand for real estate investment is starting gradually; house prices have been forcibly increased to excessive levels. When home prices rise beyond the level of living demands, speculation will appear, leading to higher vacancy rates, and hence monthly mortgage payments are higher than renting costs (Dickson, 2007).

Housing Price-to-Income Ratio is more than an international cordon; so house prices are jointly elevated by consumption demand, investment demand, and speculative demand. Earlier purchasing of properties and the initial purchase of larger homes is becoming the normal consumption behavior to cope with the rapid rise of house prices (ibid).

In recent years in China, although people's incomes have increased, the house price growth is too fast to tolerate, and this also causes huge pressure to those that buy property. The national average house price from 1999 was 1,984 yuan/square meters whereas in 2009 this had increased to 4,600 yuan/square metre (ibid). This represents a factor of increase of 2.31 (ibid). In 1999; the per capita disposable income was 5,854 yuan (ibid). In 2009, the per capita disposable income had elevated to $10,755.25$ yuan, an increase of $83.72 \%$ (ibid).

When consumers buy property, they should consider house price relative to their disposable Income; 
this is the housing Price-to-Income relationship. The Housing Price-to-Income Ratio of developed countries is 6:1 (ibid). China's Housing Price-to-Income Ratio is higher than this number; the family income to house price ration can be used as an indicator to determine whether house prices are reasonable given the level of household income. It directly reflects the matching degree regarding the level of house prices and the residents of the self-help demand.

During the period from 1996 to 2008, China's Housing Price-to-Income Ratio was in the range of 5.5-7.5 between fluctuations (THE CENTRAL PEOPLE'S GOVERNMENT, 2008). The minimum was 5.64 in 1996, whilst the highest was 7.44 in 1997 (ibid). This overall level was higher than the average level of developed countries; but the perception of many Chinese people was that the resultant economic strain was far more than that expected for this Figure.

This is because in 2008, front-line cities in China, such as Shenzhen, had much higher Housing Price-to-Income Ratio, Shenzhen's being 15.1; Shanghai exhibited a minimum of 9.7 Dickson (2007). Beijing's was 14.9 (ibid). Second line cities such as Xiamen and Hangzhou, Housing Price-to-Income Ratio were 13.1 and 10.9 respectively (ibid). In these cities, the pressure is significantly greater than other cities to buy a house. House prices were much higher than the local residents' income limits.

In June, 2011' many economists of the World Bank said at a news conference in Beijing, that the real estate bubble is one of China's biggest economic risks (Davis, 2010). Kindleberger (Feng \& Jia, 2011) mentioned; the real estate bubble can be understood as the real estate prices mounting steadily in a continuous process. The rising of prices make people perceive prices will still raise in future, and constantly attract new buyers.

Along with the rise in prices and as speculative capital continues to increase, the housing price will be much higher than the corresponding entity price, which leads to the real estate bubble. When the bubble is burst, it will cause the real estate industry to slump and result in a higher vacancy rate. Because of the real estate industries close ties to banking, the real estate bubble can also cause a wide range of economic crises and social issues (Feng \& Jia, 2011). In order to control the growth of house prices, in 2010, the Chinese government issued the "purchase restriction order". This national policy is used to control the speculative real estate investment, and hopes through the macroeconomic regulation to control the current high prices in real estate. By "purchase restriction order" influence, in 2011 the rate of increase in house prices compared with 2009 has dropped significantly (Murray, 2011).

GDP growth:

GDP growth and house prices are complementarily related; GDP will have a positive effect upon house prices that reflects the housing wealth. Use of the Granger causality test can verify this relationship between GDP and real estate prices. Real estate is a kind of important mortgaged property, when housing prices are increased, the value of the mortgaged property is also increased.

Thus it will influence the amount of wealth controlled by people and residents own lending abilities. It will also cause them to change their lending plan and credit demands, as a result real estate developers will also increase the development and investment. This kind of demand upon future earnings Published by SCHOLINK INC 
expectations will expand bank credit demands, it has great effect on new construction investment by credit availability and loan attitudes.

It will eventually lead to real estate price changes; Johnson (2010) used the PW model to analyse: In the short term, the bank credit direct influence upon real estate prices is limited. It is main long-term effect; the bank credit growth will improve the real estate prices (Johnson, 2010). According to the Johansen method and the ECM model it can be determined that GDP has a direct impact towards bank credit (ibid).

In China, the elastic coefficient of GDP for bank loans is 1.048. In the long term, when GDP is increased each 100 million RMB, bank loans will be corresponding increased by 104.8 million RMB (THE CENTRAL PEOPLE'S GOVERNMENT, 2010). Bank lending boosts consumer spending and generates the contribution to GDP. In the Granger validation method, the real estate price index is a factor when regarding bank loans.

The real estate price index for bank loans elastic coefficient is 0.352 in the long term, hence if the real estate price index were to rise by $1 \%$ on a yearly basis, bank loans will increase 035.2 million RMB. This shows that house prices are a reason for stimulating consumption loans to increase. Expectations for the rise in house prices will stimulate people to increase the demand upon the real estate industry. And as a result these increases will also further drive the people's demand of bank credit.

The prosperity of the real estate market is also influenced by GDP growth, because China's urbanisation rate is $44 \%$, whereas other developed countries urbanisation rates are around $80 \%$ (THE CENTRAL PEOPLE'S GOVERNMENT, 2010). When the country rapidly developed, the real estate industry played an important role in the national economy.

China's GDP has maintained 10\% growth since 2003, in addition even during 2008 and the world economic crisis, the growth only declined slightly and maintained a value of $9 \%$ (ibid). The real estate industry and construction industry also maintained the same growth trends, their growth even exceeded economic growth itself. For example, China's GDP in 2004 was 15.98783 trillion RMB, the growth rates were $10.1 \%$ (ibid). The added value of real estate was 717.41 billion RMB, the increase rate was $17.71 \%$ (ibid). The added value of construction was 869.43 billion RMB, the increase rate was $16.22 \%$ (ibid). In 2004 urbanisation rate was $41.76 \%$.

In 2007, the GDP was 24.95299 trillion RMB, the growth rate was $13.0 \%$ (ibid). The added value of real estate was 1.22775 trillion RMB, the increase rate was $17.74 \%$ (ibid). The added value of construction was 1.40141 trillion RMB, the increase rate was $27.04 \%$ (ibid). In 2007, urbanization rate was $44.94 \%$ (ibid).

In $1998-2008$, the construction industry was $5.64 \%$ in the mean value of GDP. It was the fourth largest contributor (ibid). The real estate industry was $4.28 \%$ in the mean value of GDP (ibid), being the seventh largest contributor. The two industries together were an average of 9.92\% (ibid). Among them, in 2007 , the contribution of construction and real estate industry was $1.65 \%$ in economic growth rate (ibid). So, the real estate industry has a very important position in the national economy. Through the 
above account, it can be seen that the real estate industry and GDP are relatively influential to each other in long term processes.

\section{Conclusion}

This paper purports the relationship between the interest rate, income, economic growth and house prices. First, interest rates in the real estate market supply and demand have a different effect upon each aspect. When real estate markets explode, it causes an increase in interest rates that will reduce the investment of real estate to a certain extent. Meanwhile, it also increases a lot of consumer investment costs.

Thus the effect of using interest rates to adjust prices is not obvious. The income of the residents will increase the demand of people for housing, but it will also increase the investment demands of people. The increase in demand also causes the increase of house prices, which leads to the range of speculative investment. The pressure of buying is enormous. The real estate bubble becomes a compelling economic risk. GDP growth influences building values and bank credit to stimulate investment needs, thus it influences house prices. The real estate industry boom also has greatly influenced the development of the national economy. So the interest rate, income, economic growth have complex and interdependent relationship with house prices.

\section{References}

Cavallo, E. (2010). Role of Relative Price Volatility in the Efficiency of Investment Allocation. Social Science Research Network (p. 3). IDB Working Paper No. 70. https://doi.org/10.2139/ssrn.1818748

Davis, B. (2010). The Great Property Bubble of China May Be Popping. A WALL STREET JOURNAL. $\begin{array}{llll}\text { Retrieved January } & 22, & 2012, & \text { from }\end{array}$ http://www.online.wsj.com/article/SB10001424052702304906004576367121835831168.html

Dickson, C. (2007). THE PROPERTY MARKET AND THE MACROECONOMY OF THE MAINLAND CHINA. HKIMR Working Paper, 5(1), 5-20.

Favara, G. (2009). Reconsidering the role of money for output, prices and interest rates. Journal of Monetary Economics, 56(3), 419-430. https://doi.org/10.1016/j.jmoneco.2009.01.002

Feng, L., \& Jia, L. (2011). Real estate bubble in China: An empirical study based on VaR model. Management Science and Engineering (ICMSE), 8(4), 2-7.

Hasson, A. (2010). China Rate Increase Gets Mixed Reaction. A WALL STREET JOURNAL. Retrieved January 20 , 2012 , from http://www.online.wsj.com/article/SB10001424052970203731004576045701209426360.html

Johnson, K. (2010). Architectural Review Boards and Their Impact on Property Price and Time-on-Market. Journal of Housing Researc, 18(1), 1-18.

LI, T. (2008). The Cheng zhong cun Land Market in China: Boon or Bane?-A Perspective on Property 
Rights. International Journal of Urban and Regional Research, 32(2), 282-304. https://doi.org/10.1111/j.1468-2427.2008.00787.x

Murray, J. (2011). Global Office Index Q3 2011. Global Foresight Series 2011, 21(4), 7.

Qi, L., \& Hua, C. (2007). Property prices and bank lending in China. Journal of Asian Economics, 18(1), 63-75. https://doi.org/10.1016/j.asieco.2006.12.013

Sloman, J., \& Garratt, D. (2010). ESSENTIALS OF ECONOMICS (5th ed., p. 77). Harlow: British Library.

THE CENTRAL PEOPLE'S GOVERNMENT. (2008). Housing policy. Retrieved from http://www.english.gov.cn/.Last accessed 22th Jan 2012

THE CENTRAL PEOPLE'S GOVERNMENT. (2010). 2001-2010 Annual Report. http://www.english.gov.cn/business.htm. Last accessed 22th Jan 2012 